Egyptian Journal of Aquatic Biology \& Fisheries

Zoology Department, Faculty of Science,

Ain Shams University, Cairo, Egypt.

ISSN $1110-6131$

Vol. 25(5): $161-171(2021)$

www.ejabf.journals.ekb.eg

\title{
Bottom trawls specifications and their relation with the stock of Rhabdosargus haffara in the Gulf of Suez, Red Sea Egypt.
}

Mohamed M. Elkohafy ${ }^{1}$, Mohsen S. Hussein ${ }^{1}$, Ahmed F. B. Abdelhamid ${ }^{1}$ Mahmoud A. Saber ${ }^{2}$, and Ahmed G. A. Gewida,"

${ }^{1}$ Department of Fish production, Faculty of Agriculture in Cairo, Al-Azhar University, Egypt.

${ }^{2}$ National Institute of Oceanography and Fisheries, NIOF. PO Box 182 Suez, Egypt.

*Corresponding author: a.gweida@azhar.edu.eg

\section{ARTICLE INFO}

\section{Article History:}

Received: Sept. 11, 2021

Accepted: Sept. 30, 2021

Online: Oct. 3, 2021

\section{Keywords:}

Trawling nets;

Body girth;

Length-weight

relationship;

Fishery management.

\begin{abstract}
This study was conducted at Attaka harbor in the Gulf of Suez (Red Sea) during the 2018-2020 fishing seasons to assess the technical specifications of trawl nets, morphometric characteristics of haffara sea bream (Rhabdosargus haffara), and their selectivity parameters. Results indicated that these trawl nets have different design characteristics; it depends on the technical characters of the trawler (i.e. horsepower, length of trawler). The hanging ratio of the bottom trawl ranged from 0.44 to 0.76 while the horizontal opening of the net ranged from 17.91 to $30.94 \mathrm{~m}$. The lengthweight relationship (LWR) of Rhabdosargus haffara had a significant correlation and the exponent $\mathrm{b}$ was observed to be 3.03. On the other hand, length-girth and length depth were analyzed and the correlation coefficients were determined to be 0.85 and 0.80 , respectively. Lengths at first capture $\left(\mathrm{L}_{50}\right)$ for male, female, and combined sexes were 12.67, 14.45 and $13.17 \mathrm{~cm}$, respectively; which were higher than the minimum landing size. This information may be used by fishery managers to get an approximate estimate of the bottom trawl effect and to design appropriate marine spatial planning.
\end{abstract}

\section{INTRODUCTION}

The Egyptian marine fisheries are suffering from many problems such as decline in marine fish production as a result of many reasons; over-fishing, some illegal fishing methods, small mesh sizes of nets which used to catch small species, establishment of new factories on the coasts, increasing in the rate of tourism from year to year and increase the percent of pollution from land-depend on sources of this pollution. As a result, it is critical to identify and establish a long-term plan to manage fishing operations, as well as to preserve and improve the development advantages that these fisheries provide (El Ganainy et al., 2005).

The harvesting potential (fishing power) of a vessel in the Gulf of Suez is also highly dependent on many other factors including availability of catch in the Gulf, the individual skipper's ability, as well as technical characteristics of all fishing methods such as gears deployed and onboard electronic equipment (El Ganiny et al., 2005; Osman et al., 2019; Saber \& Gewida, 2020 and Saber et al., 2020). 
Rhabdosargus haffara is a commercially valuable species belong to Family Sparidae (Ibrahim, 1999; Ahmed \& El-Ganainy, 2000; EL-Halfawy, 2001; ElBoray, 2003; Osman et al., 2020 and Saber et al., 2020). Its annual production has a considerable commercial importance in the Gulf of Suez. This species is caught by trawling, while it is caught in the shallow water of the Gulf of Suez in the northern of Suez by trammel nets (El Ganainy, 2017 and Saber et al., 2020).

The relation between length-girth and their parameters are important tools in the fisher's management of all fisheries especially artisanal fisheries (Jasper \& Evenson, 2006 and Saber $\boldsymbol{e t}$ al., 2020). Body length and body girth are related to some of the other biological parameters such as swimming speed and condition factor of fishes. The length and girth parameters determine if the fishnet is selective to catch a specific length and a special fish. Thus, they explain the relation between the fish and fishing methods and fish's ecological position within the food webs in which they are embedded (Hambright, 1991; Pauly, 2000 and Stergiou \& Karpouzi, 2003).

This study was conducted to observe the technical specifications of the trawl nets in the Gulf of Suez. It also focused on the morphometric characteristics of Rhabdosargus haffara and assesses the length at first capture $\left(\mathrm{Lc}_{50}\right)$ for $R$. haffara landed from trawl at the Attaka fishing Harbor, Gulf of Suez, Red Sea.

\section{MATERIALS AND METHODS}

\section{Study area:}

From Suez in the north (Lat.29 $56^{\prime} \mathrm{N}$ ) to the Island of Shadwan in the south (Lat.27 $36^{\prime} \mathrm{N}$ ), the Gulf of Suez extends for roughly 250 kilometers. The Suez Gulf is characterized by a width ranged between 20 to $40 \mathrm{~km}$, and its depth ranged between 5 to 200 meters with an average of $45 \mathrm{~m}$ (Fig. 1). The Suez Gulf is regarded one of the most productive areas along the Egyptian red sea coast since it produces more than 64 percent of all red sea fish. In the Gulf there are three main fishing methods; trawl, purse seine, and artisanal fishing (long line, trammel, and gill nets).

\section{Bottom trawls specification:}

The technical specifications of trawling gear were collected in the Attaka harbor and analyzed in this article. Some measurements are taken during the interviews with fishermen on board. The data collected includes some details on the characteristic of trawling gear (headline length, ground rope length, wing length, wing mesh, codend length, and target species, etc.), otter boards (weight, length, and height) and general fishing vessel features such as engine power.

The hanging ratio $(\mathbf{E})$ is calculated by the equation:

$$
\mathrm{E}=\frac{\mathrm{lb}}{\mathrm{n} \mathrm{MS}}
$$

Notti et al. (2013)

Where:

$\mathrm{l}_{\mathrm{b}}=$ the bosom length.

$\mathrm{n}=$ the total number of meshes in the panel along the bosom.

$\mathrm{MS}=$ the panel's mesh size (totally stretched) related to the bosom. 


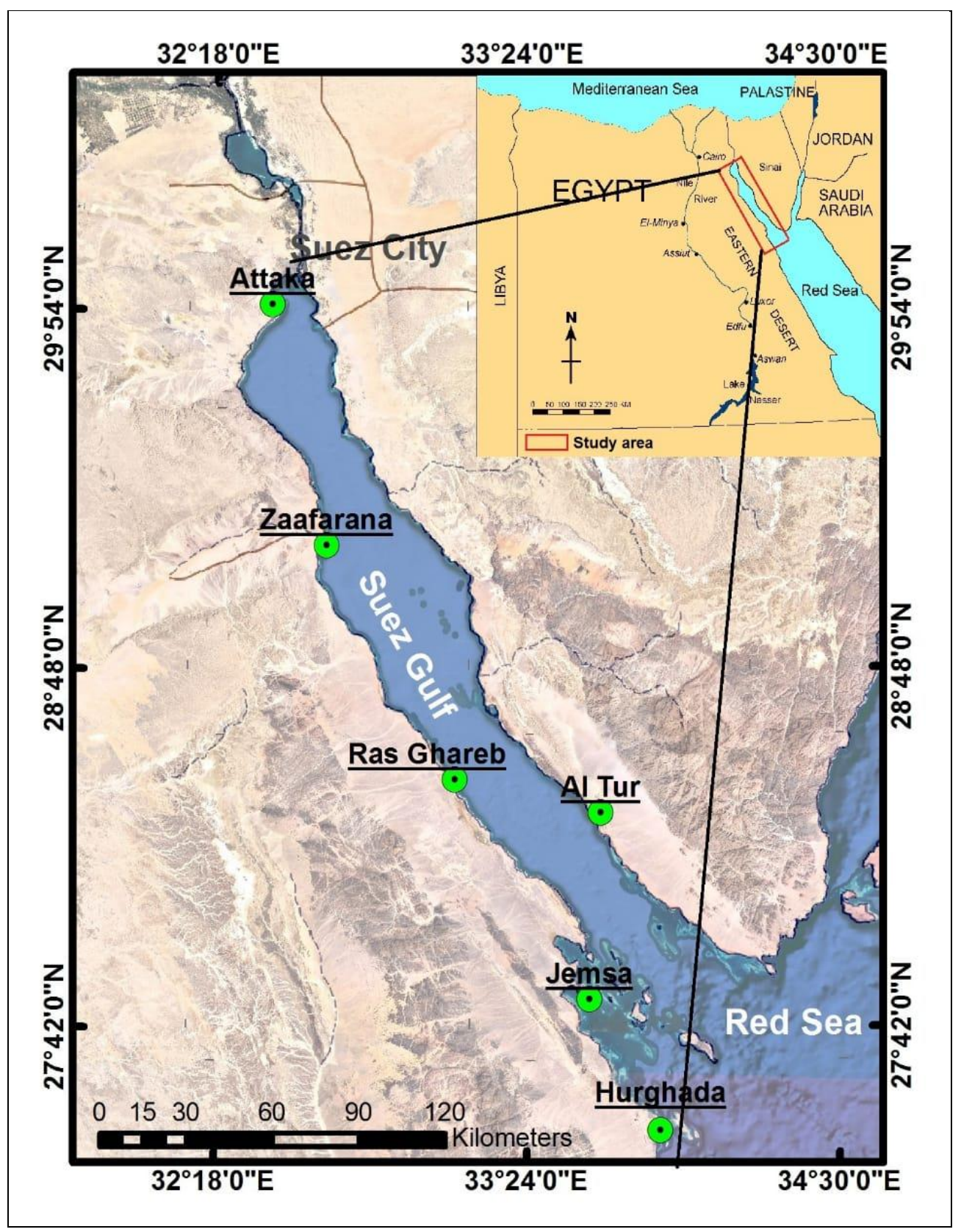

Fig. 1. A map of the Gulf of Suez, Red Sea, Egypt.

The horizontal and vertical net are affects by many factors; hanging ratio, the number of meshes corresponding to the length of bosom and the length of head rope. Overall, these parameters can change the distribution of resulting forces along the head rope: with the lower the hanging ratio its lead to longer the mesh panel length for the same bosom length, and the smaller the net openings.

The length of horizontal trawl opening (HNO) is calculated by the equation:

\section{$\mathrm{HNO}=\mathrm{HL} * \mathbf{E}_{1}$}

Notti et al. (2013)

Where:

$\mathrm{HL}=$ head rope length $(\mathrm{m})$.

$\mathrm{E}_{1}=$ the hanging ratio between rope and net.

$\mathrm{HNO}=$ the length of horizontal trawl opening $(\mathrm{m})$. 


\section{Morphometric relationships:}

The length-weight relationship and the relationship between total length (L) and total girth $(\mathrm{G})$ and total depth (D) were estimated using the following equations:

(1) The relation between body weight and body length (L-W) of all samples was calculated by the following equation:

$$
\mathbf{W}=\mathbf{a} \mathbf{L}^{\mathbf{b}}
$$

(2) Relationship between (L-G) was calculated using the following equation:

$$
\mathbf{G}=\mathbf{a}+\mathbf{b} \times \mathbf{L}
$$

(3) Relationship between (L-D) was assessed using the following equation:

$$
\mathbf{D}=\mathbf{a}+\mathbf{b} \times \mathbf{L}
$$

Where: $\mathrm{W}$ is the total weight $(\mathrm{g}), \mathrm{G}$ is the total girth $(\mathrm{cm}), \mathrm{D}$ is the total depth $(\mathrm{cm}), \mathrm{L}$ is the total length $(\mathrm{cm})$ and $\mathrm{a} \& \mathrm{~b}$ are the intercept and slope respectively (Santos et al., 2006).

\section{Selectivity parameters:}

The length-cumulative curve was used to calculate the probability of capture $\mathrm{P}$ for each length class of Haffara sea bream. The total length at initial capture $\mathrm{L}_{50}$ was calculated by plotting the cumulative probability of capture against the mid-length of the class interval. The $\mathrm{L}_{50}$ is defined as the cumulative probability at $50 \%$ of the time. This is the number of recruits at which $50 \%$ of the captures are kept by the gear or $50 \%$ of the recruits are fully exploited. The total length at $25 \%$ and $75 \%$ exploitation $\left(\mathrm{L}_{25}\right.$ and $\left.\mathrm{L}_{75}\right)$ were also calculated for Rhabdosargus haffara under investigation. Using a running average method and logs, the probabilities were smoothed.

\section{RESULTS}

\section{Bottom trawls specifications:}

The data of bottom trawl specifications: vessel characteristics (length, horsepower, fisheries depth, and target species), and gear specifications (headline, foot line, wings, and codend) were collected through interviews with the fishermen in the Gulf of Suez (Table 1).

The results of these data indicated that the bottom trawl which used in the Gulf of Suez is a modified trawl from Italian trawl (Fig. 2). The bottom trawl consists of asymmetric two-face trawl with long foot rope, different horizontal openings. Also, the bottom trawl is usually made of polyamide material (nylon) or polyethylene material (PE). The length of the ground rope ranged between 36.5 to $58.5 \mathrm{~m}$ (on average of $45.5 \mathrm{~m}$ ); head rope was ranged between 31.09 to $54.86 \mathrm{~m}$ with average of $41.53 \mathrm{~m}$. There were some accessories which base in establishing of fishing gear such as chains were set in ground rope with weight about $100 \mathrm{~kg}$ per trawl along the foot rope (Table 1). 
Table 1. Technical specifications of bottom trawl (vessel characteristics and gear specifications) through interviews with the fishermen in the Gulf of Suez.

\begin{tabular}{|c|c|c|c|c|c|c|c|c|c|c|}
\hline \multirow{2}{*}{ ID } & \multirow{2}{*}{$\begin{array}{l}\text { Vessel } \\
\text { length }\end{array}$} & \multirow{2}{*}{$\begin{array}{l}\text { Horse } \\
\text { power }\end{array}$} & \multirow{2}{*}{$\begin{array}{l}\text { Mean } \\
\text { depth }\end{array}$} & \multirow{2}{*}{$\begin{array}{l}\text { Head } \\
\text { rope }\end{array}$} & \multirow{2}{*}{$\begin{array}{l}\text { Foot } \\
\text { rope }\end{array}$} & \multicolumn{2}{|c|}{ Wings } & \multicolumn{2}{|c|}{ Cod end } & \multirow{2}{*}{$\begin{array}{l}\text { Target } \\
\text { species }\end{array}$} \\
\hline & & & & & & Mesh & Length & Mesh & Length & \\
\hline 1 & 25 & 500 & 50 & 47.549 & 54.86 & 75 & 18.63 & 10 & 12 & $\begin{array}{c}\text { Shrimp, } \\
\text { Lizardfish }\end{array}$ \\
\hline 2 & 26 & 425 & 30 & 32.91 & 36.57 & 65 & 13.71 & 15 & 20 & $\begin{array}{l}\text { Shrimp, } \\
\text { Lizard fish }\end{array}$ \\
\hline 3 & 24 & 425 & 20 & 54.864 & 58.533 & 75 & 17.801 & 15 & 12 & Lizard Fish \\
\hline 4 & 25 & 425 & 40 & 38.40 & 40.40 & 75 & 18.288 & 20 & 10.3 & Shrimp \\
\hline 5 & 24 & 500 & 35 & 43.85 & 45.72 & 65 & 17.973 & 20 & 10.3 & Shrimp \\
\hline 6 & 27 & 500 & 40 & 42.06 & 45.80 & 75 & 12.98 & 20 & 10.3 & $\begin{array}{l}\text { Shrimp, } \\
\text { Lizard fish }\end{array}$ \\
\hline 7 & 27 & 425 & 55 & 31.096 & 36.654 & 65 & 13.87 & 15 & 13.72 & Shrimp \\
\hline 8 & 25 & 425 & 40 & 44.5 & 47 & 75 & 17 & 15 & 14 & $\begin{array}{l}\text { Shrimp, } \\
\text { Lizard fish }\end{array}$ \\
\hline 9 & 19 & 350 & 25 & 35.5 & 39 & 65 & 12.5 & 20 & 10 & $\begin{array}{c}\text { Shrimp, } \\
\text { Lizard fish } \\
\text { Other species }\end{array}$ \\
\hline 10 & 18 & 230 & 40 & 37 & 40 & 65 & 13.5 & 25 & 7 & $\begin{array}{l}\text { Shrimp, } \\
\text { Lizard fish }\end{array}$ \\
\hline 11 & 21 & 385 & 40 & 36 & 40 & 65 & 12.5 & 25 & 8 & $\begin{array}{l}\text { Shrimp, } \\
\text { Lizard fish }\end{array}$ \\
\hline 12 & 28 & 565 & 70 & 45 & 48 & 75 & 18.6 & 20 & 12 & $\begin{array}{l}\text { Shrimp, } \\
\text { Lizardfish }\end{array}$ \\
\hline
\end{tabular}

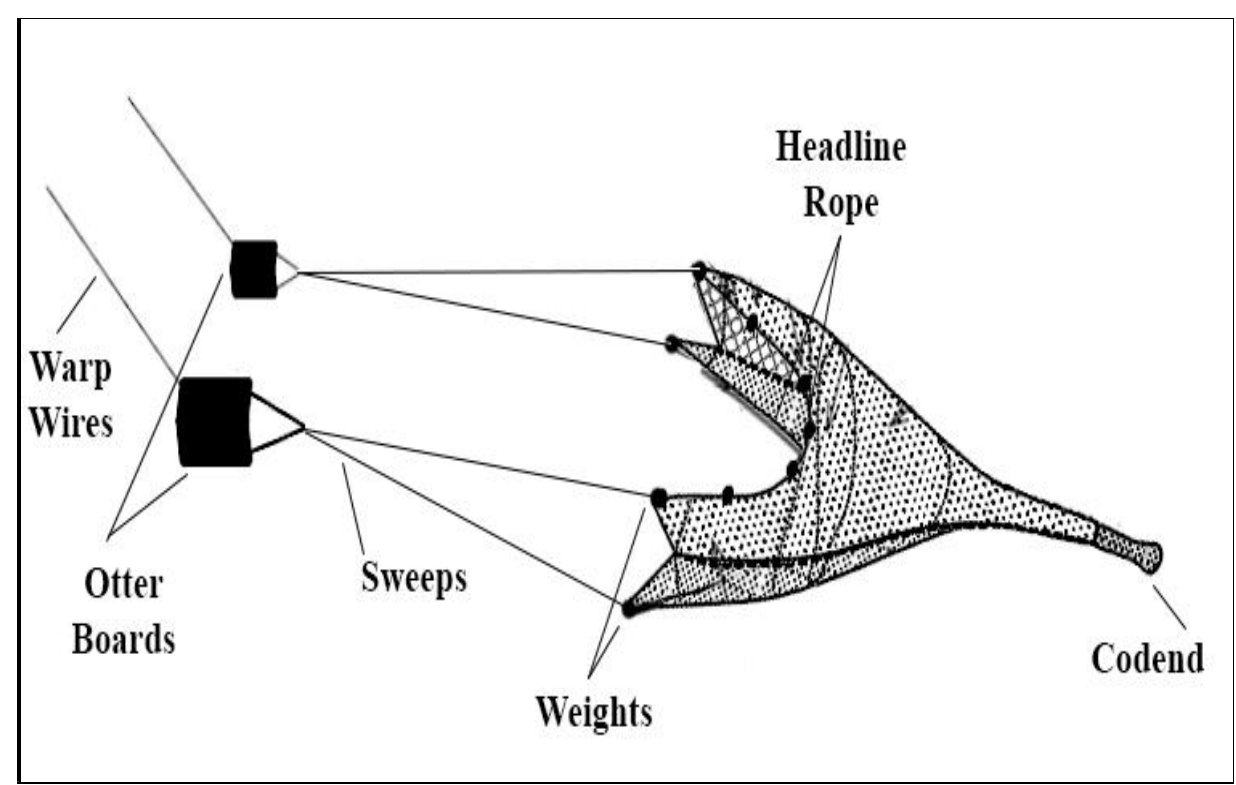

Fig. 2. Bottom trawls and their parts that work in the fisheries of the Gulf of Suez.

The Designer should be considered the relation between the size of the otter, and tire reaction to the water-flow forces which push it outward in opposition to the in-pulling forces from the warps and the body of the gear (Fig. 3). The data relating to 
the length of bosom, hanging ratio (E), and bottom trawls horizontal opening HNO, were represented in Table (2).

Table 2. Otter trawl investigation; bosom (B), hanging ratio (E), and horizontal opening (HNO) for commercial trawl in Gulf of Suez.

\begin{tabular}{ccc}
\hline $\mathbf{B}(\mathbf{m})$ & $\mathbf{E}(\boldsymbol{\%})$ & HNO $(\mathbf{m})$ \\
\hline 7 & 0.76 & 30.94 \\
7 & 0.65 & 26.46 \\
6 & 0.51 & 20.76 \\
6 & 0.44 & 17.91 \\
\hline
\end{tabular}

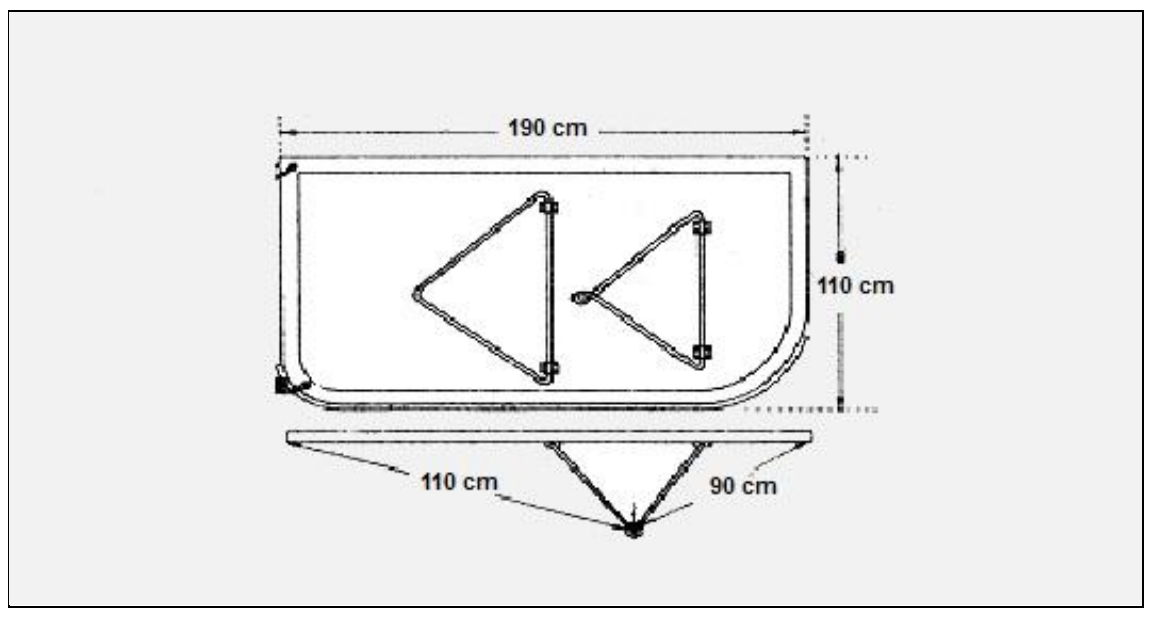

Fig. 3. General structure of otter board.

\section{Morphometric relationships:}

Length-weight (L-W) relationship is an important biological parameter needed to appreciate the suitability of the environment for any fish species. As a result of that, many fishery biological studies are focusing on this relationship. The relationships between total length (L) and total body depth (D) and total girth (G) are essential in estimating the allowable catch and appropriate mesh size to be used in a fishery.

The total lengths and weights of Rhabdosargus haffara in the Gulf of Suez ranged between $(9.9 \mathrm{~cm} / 12.49 \mathrm{~g})$ to $(23.1 \mathrm{~cm} / 193 \mathrm{~g})$ for both sex. Length-weight relationship (L-W) with power regression equation: $W=0.0134 \mathrm{~L}^{3.0343}, \mathrm{R}^{2}=0.9424$ (Fig. 4).

Length-girth relationships (L-G) are presented in Fig. (5), the exponent b value was estimated to be 0.14 for $R$. haffara. The coefficients of determination $\left(\mathrm{R}^{2}\right)$ of the L-G regressions were found to be 0.85 . The relationship between total length and body depth (L-D) is shown in Fig. (6), the regression coefficient $\left(\mathrm{R}^{2}\right)$ was estimated to be 0.80 . 


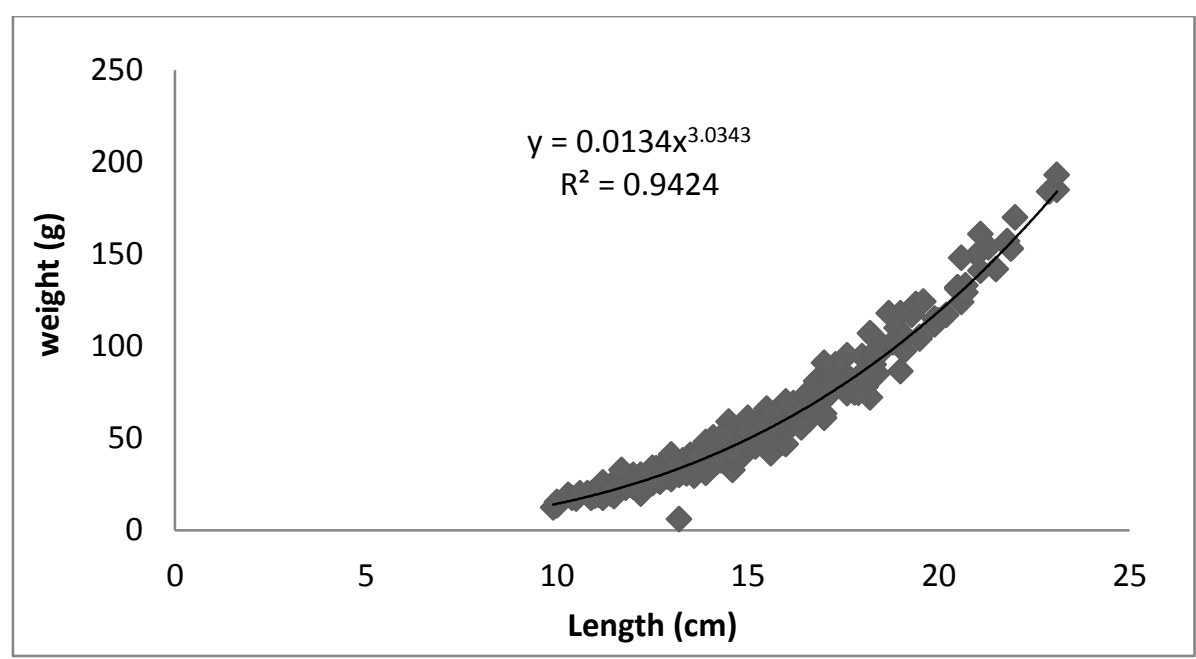

Fig. 4. Length-weight relationship of $R$. haffara captured by trawl net in Gulf of Suez.

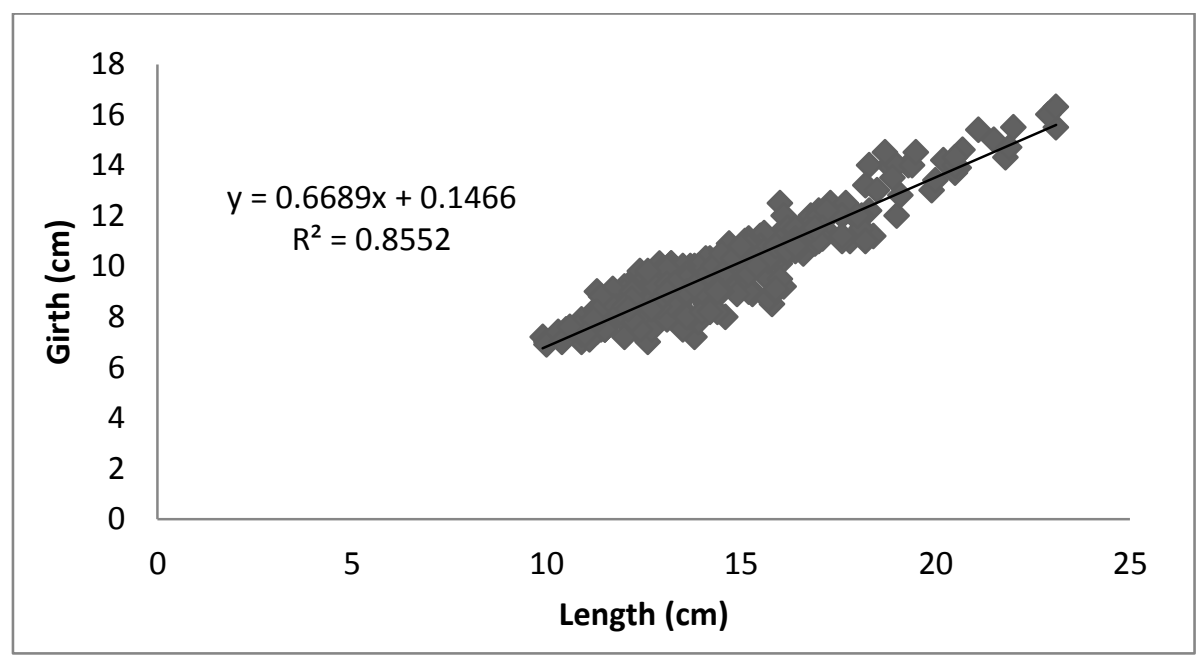

Fig. 5. Length-girth relationship of $R$. haffara captured by trawl net in Gulf of Suez.

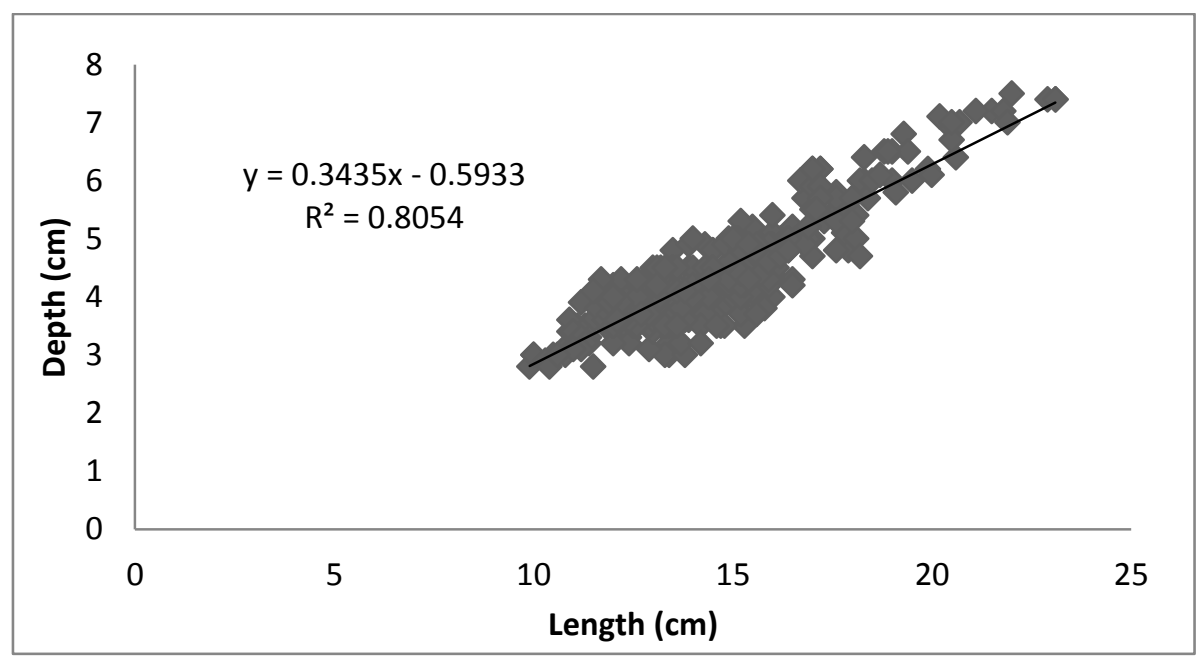

Fig. 6. Length-depth relationship of $R$. haffara captured by trawl net in Gulf of Suez. 


\section{Selectivity parameters:}

The computed length-at-first capture, $\mathrm{L}_{50}$ or Lc (length at which $50 \%$ of $R$. haffara entering the gear are retained) was $13.17 \mathrm{~cm}$ for combined sexes, 12.67 for males, and $14.45 \mathrm{~cm}$ for females (Fig. 7), by cumulated catch curve and running average routines.

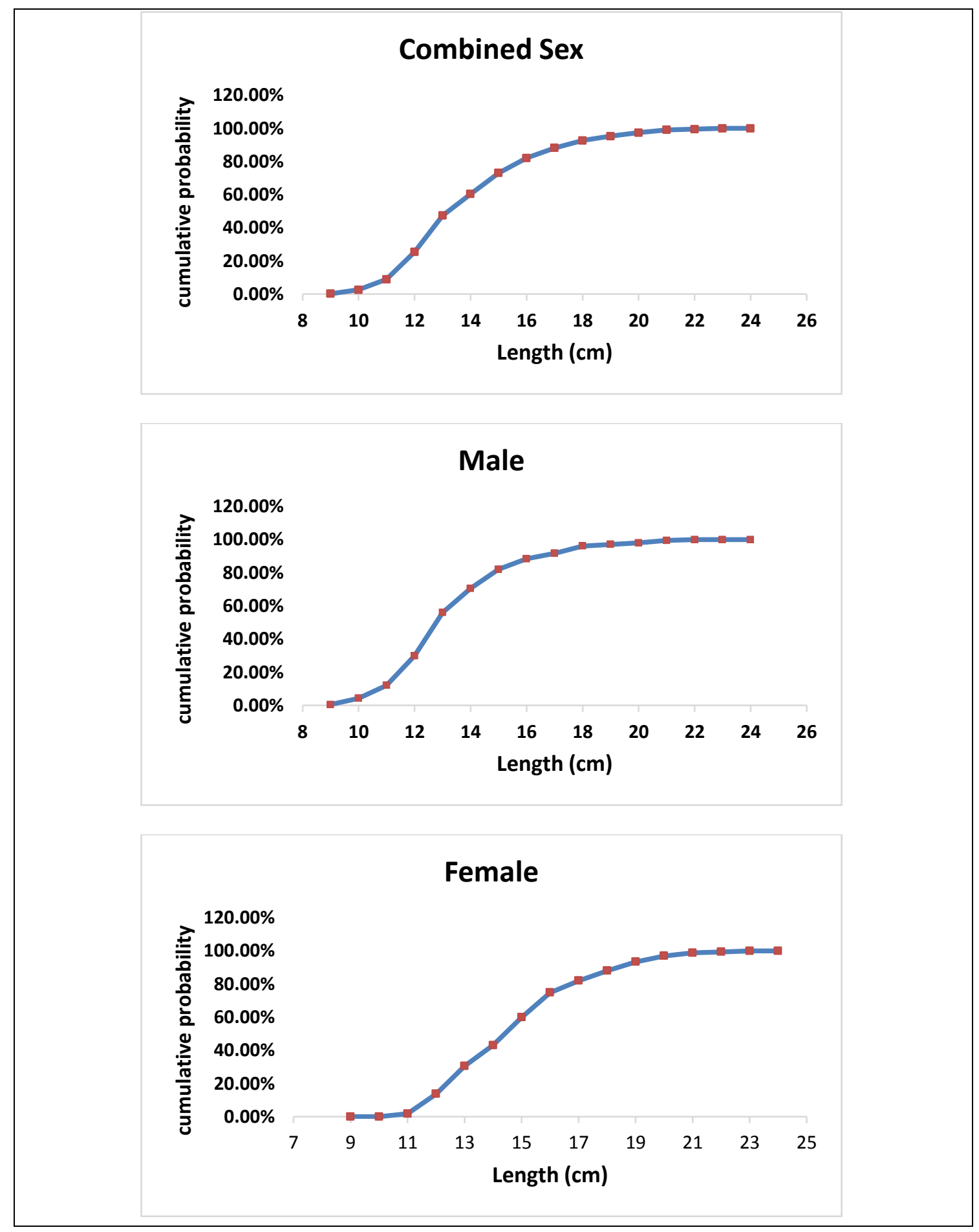

Fig. 7. Length at first capture $\left(\mathrm{Lc}_{50}\right)$ of combined sex, male, and female of $R$. haffara landed by trawl net at the Attaka fishing harbor, Gulf of Suez. 


\section{DISCUSSION}

Bottom trawls are often used to capture shrimp and bottom fish at depths ranging from shallow coastal waters to depths (Morgan \& Chuenpagdee, 2003). Between 2000 and today, the number of trawl vessels operating in the Gulf of Suez has fluctuated between 72 and 78. The vessel lengths ranged from 20 to $30 \mathrm{~m}$, with horse power ranging from 200 to 600 horsepower, with the majority (68 boats) being 400-600 horsepower (Mehanna \& El-Gammal, 2007).

Nine hundred meshes and bigger sizes trawl nets are used generally in Gulf of Suez to catch commercially important species mainly shrimp (Penaeus semisulcatus, Marsupenaeus japonicus, and Metapenaeopsis stridulans), hake (Saurida undosquamis), and Mullidae as well as Sparidae members (Rhabdosargus haffara) are often targeted with 900 mesh and smaller sizes trawl nets (El Ganainy et al., 2005; Mehanna \& El-Gammal, 2007 and Osman et al., 2019).

The major technical element determining bottom trawl selectivity in the Gulf of Suez is codend mesh opening (Saber et al., 2020). In Egypt, most fishing gear has tiny mesh sizes, resulting in a high proportion of small fish and juveniles in the catch. The horizontal net opening ranged between 17.9 to $30.94 \mathrm{~m}$. These results are higher in comparison of horizontal net opening in the Mediterranean Sea, Egypt (Lucchetti et al., 2016).

The current results can be used as support to the management of trawl fisheries in the Gulf of Suez, specifically for the stock of Rhabdosargus haffara. Technical specifications in this study are limiting in the Red Sea and Gulf of Suez. Some dimensions of all parts of trawl like headline, footrope, codend, and otter board are basically for trawl fishery management.

Sparidae is one of the most commercial families in the Gulf of Suez fisheries (Osman et al., 2019 and Saber et al., 2020). Rhabdosargus haffara is the most common Sparid species in trawl and artisanal catches. Family Sparidae is one of the considerable commercial families in the large industrial and small scale fishery in the Gulf of Suez with most dominant species Rhabdosargus haffara (Osman et al., 2019, and El-Boraay, 2004).

The relation between length-girth with other biological parameters (behavior of fish) and technical aspects (gear construction, dimensions, and fishing techniques) determining the size selectivity of fishing gear were discused by Santos et al. (1998) and Stergiou \& Karpouzi (2003). In the present study the length at 50\% capture was $13.17 \mathrm{~cm}$ for combined sexes, $12.67 \mathrm{~cm}$ for male, and $14.45 \mathrm{~cm}$ for female. In comparison of the length at first capture of male, female, and combined sexes which assessed for species are slightly higher than what was reported by El-Boraay (2004) who estimated the $\mathrm{Lm}_{50}$ for male Rhabdosargus haffara as $10.3 \mathrm{~cm}$ in the Suez bay.

The length at first maturity $(\operatorname{Lm} 50=12.3$ and 12.7 for male and female, respectively) which assessed by Osman $\boldsymbol{e t}$ al. (2020) were relatively lower than the length at first capture for male, female, and combined sexes which observed in the present study. This indicated that the stocks of this species are harvested after they reach the matured stage. These differences may be attributed to the different recorded maximum length of the species in the different localities. 


\section{CONCLUSION}

In the present study we observed the trawl fishing net that used in the Gulf of Suez have two faces. Some technical parameters of bottom trawl were assessed to be available to fisheries manager. The lengths of mesh size have ranged between 65 for wings to $10 \mathrm{~mm}$ for codend. The fisheries manager should be consider the use of square mesh cod ends, modification of otter trawl, modification of trawl vessel is mandatory in Red Sea and Gulf of Suez. Furthermore, because to the high fishing pressure, bottom trawling in critical regions such as reproductive and nursery areas should be prohibited. The current results can be used as support to the management of trawl fisheries overall and for Rhabdosargus haffara fisheries in the Gulf of Suez.

\section{REFERENCES}

Ahmed, A.I. and A. El-Ganainy (2000). On the population dynamics of three sparid species from south Sinaicoast of the Gulf of Suez, Red Sea. Journal of Fisheries and Aquatic Science, 4: 235-264.

El-Boray, K.F. (2003). Hermaphroditism of Rhabdosargus haffara (Teleostei: Sparidae) from Suez Bay, Red Sea. Egyptian Journal of Aquatic Research, 29: 177-192.

El-Boray, K.F. (2004). Reproductive biology and histological characters of male Rhabdosargus haffara (Teleostei; Sparidae) from Suez Bay, Red Sea. Egyptian Journal of Aquatic Research, 30: 226-233.

El-Ganainy, A. A. (2017). Stock assessment and gear description of the Red Sea and Gulf of Suez fisheries for their proper management. Final report submitted to Science and Technology Development Fund STDF, Ministry of scientific Research, Egypt, 124pp.

El-Ganainy, A.A.; Yassien, M.H. and Ibrahim, E.A. (2005). Bottom trawl discards in the Gulf of Suez, Egypt. Egyptian Journal of Aquatic Research, 21: 240255.

El-Halfawy, M.M. (2001). Effect of types of food on the development, Growth and biochemical composition of the fish Rhabdosargus Haffara (Farsskal, 1775), (Family: Sparidar) in the North Suez Gulf', Ph.D. Thesis, Zoology Department, Faculty of Scince, Suez Canal Univirsity.

Hambright, K.D. (1991). Experimental analysis of prey selection by largemouth bass: role of predator mouth width and prey body depth. Transactions of the American Fisheries, 120: 500-508.

Ibrahim, A.E.A. (1999). Biological and ecological studies on some sparidae fishes at Southern Sinai Coasts, Red Sea. Ph.D. Thesis, Faculty of Science, Suez Canal University, Egypt.

Jasper, J.R. and Evenson, D. F. (2006). Length-girth, length-weight, and fecundity of Yukon River Chinook salmon Oncorhynchus tshawytscha (Alaska Department of Fish and Game, Fishery Data Series, 6-70.

Lucchetti, A.; Kholeif, S.E.A.; Mahmoud, H.H. and Notti, E. (2016). Towards sustainable fisheries management in emerging markets: An overview of properties, gaps and opportunities in Egypt. Marine Policy, 72: 1-10. 
Mehanna, S.F. and El-Gammal F.I. (2007). Population characteristics and reproductive dynamics of the thinlip mullet Liza ramada (Risso, 1810) at Suez Canal Lakes, Egypt. Egyptian Journal of Aquatic Biology and Fisheries, 11: 307324.

Morgan, L.E.; Chuenpagdee, R. and Reichert, J. (2003). Shifting Gears: Addressing the Collateral Impacts of Fishing Methods. In USA Waters. Island Press Publication Services.

Notti, E.; De Carlo, F.; Brčić, J.; Sala, A. and Paschen, M. (2013). Technical specifications of Mediterranean trawl gears. Contributions on the Theory of Fishing Gears and Related Marine Systems. University of Rostock, Department of Mechanical Engineering and Marine Technology, 8: 162-169.

Osman, H.M.; Saber, M.A. and El-Ganainy, A.A. (2019). Population structure of the striped piggy Pomadasys stridens in the Gulf of Suez. Egyptian Journal of Aquatic Research, 45: 53-58.

Osman, M.H.; Saber, A.M.; El-Ganainy, A.A. and Shaaban, M.A. (2020). Fisheries biology of the haffara bream Rhabdosaragus haffara (Family: Sparidae) in Suez Bay, Egypt. Egyptian Journal of Aquatic Biology and Fisheries, 24: 361372.

Pauly, D. (2000). Predator-Prey Ratios in Fishes. In: Froese, R., Pauly, D. (Eds.), FishBase 2000: Concepts, Design and Data Sources. ICLARM, Manila. 361pp.

Saber, A.M.; Osman, M.H.; El-Ganainy, A.A. and Shaaban, M.A. (2020). Species composition, length-weight relationships and condition factor of commercial species grasped by trammel nets and gill nets in the Gulf of Suez, Red Sea, Egypt. Egyptian Journal of Aquatic Biology and Fisheries, 24: 145-156.

Saber, M.A. and Gewida A.G.A. (2020). The influence of trammel net fishing on the Rabbit fish (Siganus rivulatus) stocks in Suez Gulf, Red Sea, Egypt. Egyptian Journal of Aquatic Biology and Fisheries, 24: 135-145.

Santos, M.N.; Canas, A.; Lino, P.G. and Monteiro, C.C. (2006). Length-girth relationships for 30 marine fish species. Fisheries Research, 78: 368-373.

Santos, M.N.; Monteiro, C.C.; Erzini, K. and Lasserre, G. (1998). Maturation and gill-net selectivity of two small sea breams (genus: Diplodus) from the Algarve coast (south Portugal). Fisheries Research, 36: 185-194.

Stergiou, K.I. and Karpouzi, V.S. (2003). Length-girth relationships for several marine fishes. Fisheries Research, 60: 161-168. 